\title{
Atualidade de Vigotski ${ }^{\star}$
}

\author{
Elizabeth Tunes $\star \star$ \\ Centro Universitário de Brasília, Brasília, DF, Brasil \\ Universidade de Brasília, Brasília, DF, Brasil
}

\begin{abstract}
Resumo
No presente texto, discute-se a atualidade da teoria histórico-cultural elaborada por Lev Semionovitch Vigotski entre, aproximadamente, o final da segunda década e a terceira década dos anos de 1900. Adota-se atitude crítica em relação à ideia de que o conhecimento científico tem prazo de validade, procurando-se mostrar que ela decorre do processo de transformação da ciência em mercadoria. Como um contraponto a essa visão, argumenta-se que todo artifício construído pelo homem apresenta algo de permanente, quando transcende a mera funcionalidade das coisas produzidas para consumo. Ou, dizendo em outros termos, tudo o que é singular, de certa forma, tem permanência no mundo.
\end{abstract}

Palavras-chave: conhecimento científico; teoria histórico-cultural; prazo de validade.

\section{Vygotsky in present days}

\begin{abstract}
In this paper, we discuss the topicality of the cultural-historical theory developed by Lev Semionovitch Vygotsky approximately between the end of the second decade and the third decade of the 20th century. We adopt a critical attitude towards the idea that scientific knowledge has an expiration date, and we seek to show that this idea emerges from the transformation of science into a commodity. As a counterpoint to this view, we argue that every device built by man presents something permanent which transcends the mere functionality of things produced for consumption. In other words, we argue that anything that is singular, in a way, has permanence in the world.
\end{abstract}

Keywords: scientific knowledge; cultural-historical theory; expiration date.

In contemporary society, which praises endless consumption, the main utility criterion is time, or, in more colloquial words, the expiration date. Everything, from the milk on the shelves of a supermarket to the books on the shelves at home, is judged by its age.

Approximately 30 years ago, Brazil watched the growth of popularity of a theory and of a scholar in the field of Education and Psychology. By the end of the 70s and early 80s, Vygotsky's ideas, as well as his disciple's, started spreading in the country. Those ideas were tagged as "historical-cultural perspective of Psychology". That perspective became gradually known and, sometimes, was distorted as a consequence of careless translations and ideological preferences of their consumers (PRESTES, 2010). In the beginning, because of everyone's mistrust, that perspective was shadowed by another popular scholar - Jean Piaget. However, it soon got past him, and became a canon in the field of education. Vygotsky's theory surpassed Piaget's in terms of popularity, but both theories coexist, albeit with frequent hasty approximations that flabbergast the experts in their theories.

The popularization of theories and scholars in the fields of Psychology and Education calls to mind the consumption of clothes and beauty products. One wears or uses what is fashionable. The product wears out not because it has been extensively used, but because of a simple convention: it is not fashionable anymore. It does not wear off; it remains somewhere, in a closet, useless.

\footnotetext{
$\star$ Translation by Larissa Tunes da Silva, to whom the author thanks.

$\star \star$ Mailing address: Universidade de Brasília, Faculdade de Educação. Campus Asa Norte - ASA NORTE. CEP: 70000-000 - Brasília, DF - Brasil.

E-mail: bethtunes@gmail.com
}

This cosmetic approach to the theory became possible, in current days, as a consequence of the creation of a new fictitious commodity: knowledge. Silva (2005) demonstrates how a new fictitious commodity - scientific knowledge - is contemporarily created, in addition to the preexisting commodities work, land and money. The author analyzes the implications of this process to the contemporary world. In her words:

The current transformation, which consists of converting production into information, is characterized by the migration form industry to services. This process is in advanced stages in developed countries. The production of knowledge, or the industrial and agricultural production, converted into information, is the most prominent productive sector in global economy, which demonstrates the importance of commoditization of knowledge to contemporary world. [...] The cause of the creation of the fictitious relation commodity-knowledge is related to the intrinsic need of capital expansion. If such need is not fulfilled, the system collapses (SILVA, 2005, p. 7).

The expansion to which the author refers means the constant growth of consumption. She points out that, since the capital's growth is menaced by the finiteness of resources, producing immaterial goods, such as knowledge, is the solution.

Since scientific knowledge is considered a commodity, it is not surprising that the expiration date criterion also applies to it. Maybe such criterion lies in the basis of the popularity drop of a scholar and his theory. Would that be the case of Piaget, in the field of Psychology and Education? Might that also take place with the historical-cultural perspective, developed by Vygotsky? 


\section{A theory with an expiration date?}

Vygotsky started his scientific production in the field of Education and Psychology in the 1920s. Therefore, approximately 90 years have passed since his first theoretical formulations. During many of those years, his works were kept in limbo for reasons that were, in a way, known. The arrival of his ideas to the western world happened, thus, many years after their production. Nevertheless, they landed here and found breeding ground. Today, the number of researchers inspired by those ideas is quite large. That fact only is enough to attest the topicality of his theories.

However, in Brazil, some symptoms of his theory's expiring start to come up. It is not rare for university professors and researchers to say that his ideas are outdated and should be replaced by more recent ones. Is it valid to say that an idea, a thought or a theory are outdated? As we intend to show henceforth, the answer to this question depends on the type of relation that is established with knowledge.

When discussing the durability of the world, Hannah Arendt (1998, p. 136) utters that the endless variety of things produced by homo faber, if properly used, will not disappear, giving "the human artifice the stability and solidity without which it could not be relied upon to house the unstable and mortal creature which is man". Since they are durable, they are relatively independent from the man that crafts and uses them. In that sense, they stabilize human life: "their objectivity lies in the fact that $[\ldots]$ men, their ever-changing nature notwithstanding, can retrieve their sameness, that is, their identity, by being related to the same chair and the same table" (ARENDT, 1998, p. 137).

The author highlights that man-made things may have value, whether of use or of exchange, considering value as "an idea of proportion between the possession of one thing and the possession of another in the conception of man" (ARENDT, 1998, p. 163). However, she states that the human artifice, although not being consumed, wears away with its use, i.e., its durability is not absolute. In other words, the use wears away the human artifice.

Arendt admits that there are man-made objects which are completely useless, and, given their singularity, are not interchangeable (they can only be priced arbitrarily), that is, they have no exchange value, nor use value - a work of art is not strictly "used". According to her, art has survived its separation from religion, magic and myth. Thus, the extraordinary permanence of works of art makes them

$[\ldots]$ the most intensely worldly of all tangible things; their durability is almost untouched by the corroding effect of natural processes, since they are not subject to the use of living creatures, a use which, indeed, far from actualizing their own inherent purpose - as the purpose of a chair is actualized when it is as upon - can only destroy them. Thus their durability is of a higher order than that which all things need in order to exist at all; it can attain permanence throughout the ages (ARENDT, 1998, p. 167)
Proceeding with her argument, the author says that some permanence is inherent to all things as things, because everything that indeed exists necessarily appears; and if something appears, it is because it has "a shape of its own; hence there is in fact no thing that does not in some way transcend its functional use" (ARENDT, 1998, p. 173). In other words, "the singularity of a work", as it allows it to transcend the functional use, provides it with some permanence in the world. It is worth, as a conclusion, to quote the author's words:

The man-made world of things, the human artifice erected by homo faber, becomes a home for mortal men, whose stability will endure and outlast the ever-changing movement of their lives and actions, only insomuch as it transcends both the sheer functionalism of things produced for consumption and the sheer utility of objects produced for use (ARENDT, 1998, p. 173)

One cannot doubt in any way the originality of Vygotsky's works. Besides, they are extensive and deal with essential areas of Psychology and Education. He systematically studied the relation between thinking and speech, the origin and development of superior psychic functions - especially their ontogenesis -, the psychology of adolescents, the psychology of art, emotions, the issue of conscience, and, most regularly, the issues related to atypical development and education of defective childhood. With methodical rigor, he systematized his ideas in all those fields, offering original contributions to issues of high importance to Psychology and Education.

Considering what has been presented so far, vigorous and singular theories, such as Vygotsky's, certainly do not have an expiration date. Even if his theory happens to lose popularity, it will remain in the world. One can say that his theory "houses the unstable and mortal creature which is man", as said Arendt (1998, p. 150). However, despite vigorous and singular, theories may seem dead if seen as the science of the society of information from late $20^{\text {th }}$ century, originated from deep changes caused by the commodification of knowledge, which brought into scientific activity the priority of utilitarian requests.

In this regard, Feyerabend (1985, p.291) states

As opposed to its immediate predecessor, late 20th-century science has given up all philosophical pretensions and has become a powerful business that shapes the mentality of its practitioners. Good payment, good standing with the boss and the colleagues in their 'unit' are the chief aims of these human ants who excel in the solution of tiny problems but who cannot make any sense of anything transcending their domain of competence. Humanitarian considerations are at a minimum and so is any form of progressiveness that goes beyond local improvements.

\section{Vygotsky's science: rooting in culture}

The beginning of Vygotsky's scientific career takes place in the early years of the great Russian Revolution, which, among other factors, played a key role in defining his way of making science and differentiated it from the 
eastern way. Alexander Romanovich Luria (1902-1977), his colleague and collaborator, made a personal assessment of the Soviet psychology:

In comparing my experiences with those of Western and American psychologists, there is one important difference. Many European and American psychologists possess outstanding personal gifts. Like good scientists anywhere, they have made their share of important discoveries. But most of them have spent their lives in a comparatively quiet, slow-moving environment. Their stories reflect the course of their work as well as the people and events that have shaped them: their parents, teachers, colleagues, and the intellectual issues in which they have participated. Their work as scholars consists of doing research and sometimes moving from university to university (LURIA, 1979, p. 17).

Instead of a disciplined career, in a still environment, Luria's generation lived within the atmosphere of a rapidly changing society: "My entire generation was infused with the energy of revolutionary change - the liberating energy people feel when they are part of a society that is able to make tremendous progress in a very short time" (LURIA, 1979, p. 17). In his work, Luria describes the strong emotions and feelings that spread through his generation, and the numerous opportunities of acting beyond a limited circle of friends and relatives. He highlights the fact that, for the first time in Russia, people could choose their careers, despite their social background. The emotional and enthusiastic environment described by him evokes John Reed's Ten days that shook the world (2006) - which was reviewed and praised by Vygotsky (1988). According to Prestes (2010), in the 20s, a decade of intense vygotskyan production, the efforts were concentrated in what was assigned by the Revolution. It was a transition period and many internal disputes were going on. The tough reality faced by the country highlighted the urgent problems that had to be solved. The need for everyone's collaboration demanded, thus, an environment of freedom and intellectual autonomy.

Vygotsky's science was developed in a work environment with a lot of enthusiasm and with a great commitment in rebuilding Psychology for the new men and for the new rising society. This commitment implied the mastering of the existing knowledge. Thus, his group diligently studied authors such as Kurt Lewin, Stern, Bühler, Köhler, and many others, who, according to Luria (1979), were practically unknown by American psychologists. Besides, Vygotsky insisted that research work in Psychology should not be apart from the real world. Instead, it should first and foremost focus on "the central problems of human existence" (LURIA, 1979, p. 53), as they are experienced at school, at work and in other contexts of human life.

According to Silva (2005), true scientific knowledge is a result of an authentic dialogue with the real world, and it is rooted, since it cannot be dissociated from the personal reality of those who utter the scientific discourse. Vygotsky's science is, thus, rooted in time and in culture: in order to carry it out, he would start from the concrete social man, and he would address himself to that man. As Zinchenko (1999) points out, he was not just an administrator of science, he was a free scientist who uttered their own ideas and judgements and even after the collapse of communist ideology, in 1991, he is still important: "Vygotsky is a whole epoch of our psychology, an epoch not because his theory is 'omnipotent because it is true', but because it is intelligent, cultured, historical, and, consequently, always timely and always interesting" (ZINCHENKO, 1999, p. 4).

The topicality of Vygotsky's ideas is also attested by the fact that they inspire a great number of scholars and researchers, inviting them and challenging them to think about Psychology and its relation to education from perspectives not yet considered. The works presented next are evidence of what has been said herein.

\section{References}

ARENDT, H. The human condition. Chicago: The University of Chicago Press, 1998.

FEYERABEND, P. Contra o método. Tradução de Octanny S. da Mota e Leônidas Hegenber. Rio de Janeiro: Francisco Alves, 1985.

LURIA, A. R. The making of mind: a personal account of Soviet Psychology. Cambridge: Harvard University Press, 1979.

PRESTES, Z. R. Quando não é quase a mesma coisa: análise de traduções de Lev Semionovitch Vigotski no Brasil - repercussões no campo educacional. 2010. Tese (Doutorado___Universidade de Brasília, Brasília, 2010.

REED, J. Ten days that shook the world. New York: Dover Publications, 2006.

SILVA, G. T. Sobre raizes e utopias: caminhos contemporâneos do desenvolvimento situado. 2005. Tese (Doutorado)Universidade de Brasília, Brasília, 2005.

VIGOTSKI, L.S. Recension del libro de John Reed, Diez Días que Conmovieron al Mundo. In:___ El dessarrollo cultural del niño y otros textos inéditos. Buenos Aires: Almagesto, 1988. p. 97-103.

ZINCHENKO, V. P. Foreword. In: VYGODSKAIA, G. L.; LIFANOVA, T. M. Lev Semenovich Vygotsky. Journal of Russian and East European Psychology, v. 37, n. 2, 1999. p. 3-12.

Received: August 29, 2013

Accepted: November 12, 2014 